Provided for non-commercial research and education use. Not for reproduction, distribution or commercial use.

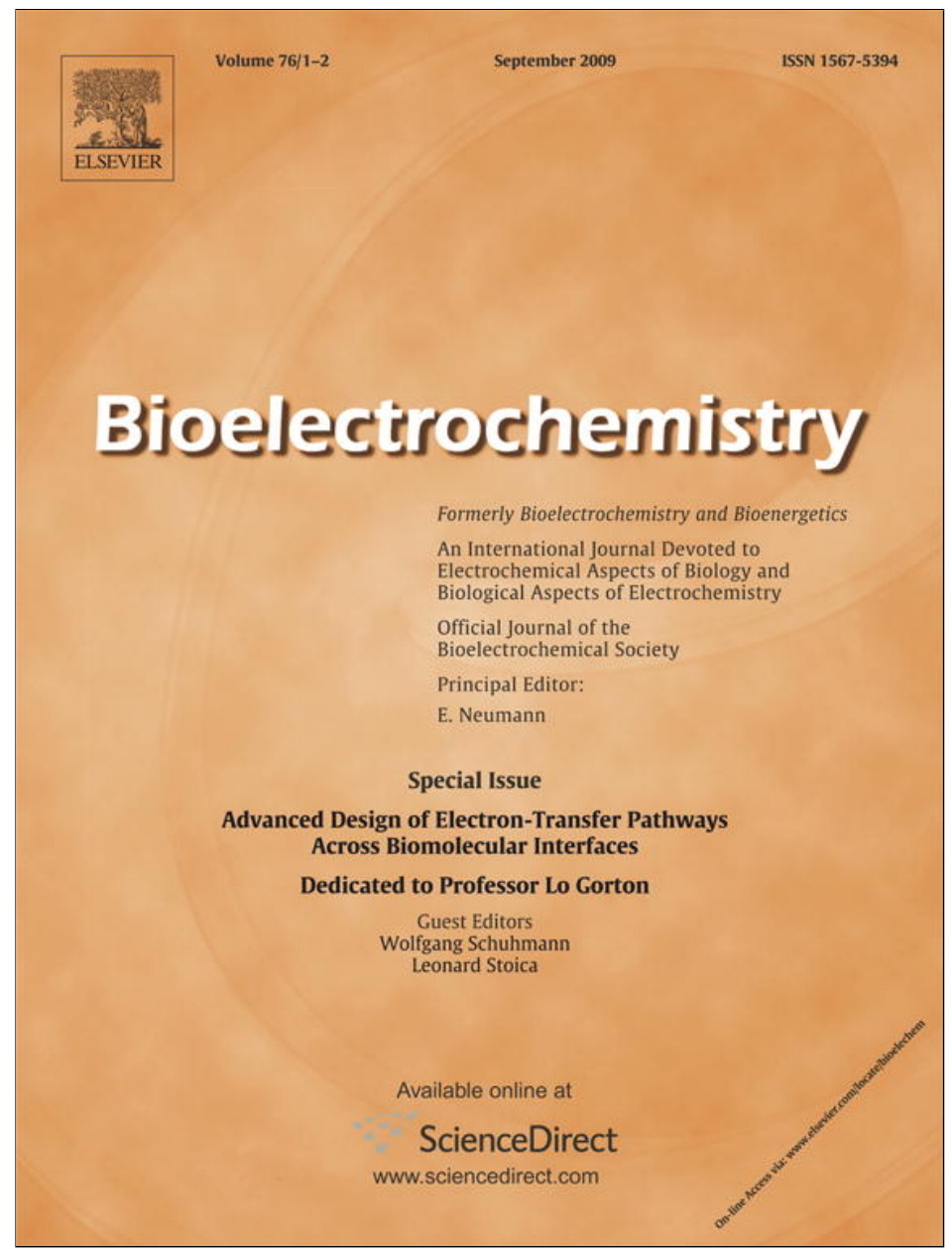

This article appeared in a journal published by Elsevier. The attached copy is furnished to the author for internal non-commercial research and education use, including for instruction at the authors institution and sharing with colleagues.

Other uses, including reproduction and distribution, or selling or licensing copies, or posting to personal, institutional or third party websites are prohibited.

In most cases authors are permitted to post their version of the article (e.g. in Word or Tex form) to their personal website or institutional repository. Authors requiring further information regarding Elsevier's archiving and manuscript policies are encouraged to visit:

http://www.elsevier.com/copyright 


\title{
Direct electron transfer reactions between human ceruloplasmin and electrodes
}

\author{
Karolina Haberska ${ }^{\mathrm{a}, \mathrm{b}}$, Cristina Vaz-Domínguez ${ }^{\mathrm{c}}$, Antonio L. De Lacey ${ }^{\mathrm{c}}$, Marius Dagys ${ }^{\mathrm{d}}$, \\ Curt T. Reimann ${ }^{\mathrm{b}}$, Sergey Shleev ${ }^{\mathrm{a}, \mathrm{b}, \mathrm{e}, *}$ \\ a Malmö University, Södra Förstadsgatan 101, 20506 Malmö, Sweden \\ b Lund University, Getingevägen 60, 22100 Lund, Sweden \\ c Instituto de Catálisis, CSIC, c Marie Curie 2, Cantoblanco, 28049 Madrid, Spain \\ ${ }^{\mathrm{d}}$ Institute of Biochemistry, Mokslininku 12, 08662, Vilnius, Lithuania \\ e A.N. Bach Institute of Biochemistry, Leninsky Prospekt 33, 119071 Moscow, Russia
}

\section{A R T I C L E I N F O}

\section{Article history:}

Received 18 December 2008

Received in revised form 20 May 2009

Accepted 22 May 2009

Available online 31 May 2009

\section{Keywords:}

Ceruloplasmin

T1, T2, and T3 copper sites

T2/T3 copper cluster

Direct electron transfer reactions

\begin{abstract}
A B S T R A C T
In an effort to find conditions favouring bioelectrocatalytic reduction of oxygen by surface-immobilised human ceruloplasmin (Cp), direct electron transfer (DET) reactions between $\mathrm{Cp}$ and an extended range of surfaces were considered. Exploiting advances in surface nanotechnology, bare and carbon-nanotube-modified spectrographic graphite electrodes as well as bare, thiol- and gold-nanoparticle-modified gold electrodes were considered, and ellipsometry provided clues as to the amount and form of adsorbed Cp. DET was studied under different conditions by cyclic voltammetry and chronoamperometry. Two Faradaic processes with midpoint potentials of about $400 \mathrm{mV}$ and $700 \mathrm{mV} v$ s. NHE, corresponding to the redox transformation of copper sites of $\mathrm{Cp}$, were clearly observed. In spite of the significant amount of Cp adsorbed on the electrode surfaces, as well as the quite fast DET reactions between the redox enzyme and electrodes, bioelectrocatalytic reduction of oxygen by immobilised $\mathrm{Cp}$ was never registered. The bioelectrocatalytic inertness of this complex multi-functional redox enzyme interacting with a variety of surfaces might be associated with a very complex mechanism of intramolecular electron transfer involving a kinetic trapping behaviour.
\end{abstract}

(c) 2009 Elsevier B.V. All rights reserved.

\section{Introduction}

Ceruloplasmin (ferroxidase, iron(II):oxygen oxidoreductase, EC 1.16.3.1) is one of the most complex blue multicopper oxidases [1,2]. The complete function of human ceruloplasmin (Cp) is not fully understood because of its sheer complexity - it shares functional characteristics with ferroxidase, amine and NO oxidase, and nitrite synthase, displays antioxidant activity, and is associated with copper and iron transport in the human body [3-8]. Knowledge on the general redox properties of $\mathrm{Cp}$ might give insights into the possible roles of this multi-functional enzyme in the human body [3-5,8], which is an important question because of the medical significance of the protein first suggested in 1952 [9]. Moreover, electrochemical investigations of direct electron transfer (DET) reactions of Cp might enable the development of biocompatible and efficient cathodes for potentially implantable biofuel cells [10,11], if bioelectrocatalytic reduction of $\mathrm{O}_{2}$ by the protein is achieved.

Human Cp is a $132 \mathrm{kDa}$ monomer with a significant amount of glycosylation (7-8\%) [12]. In contrast to the three-domain structures

\footnotetext{
* Corresponding author. Biomedical Laboratory Science, Faculty of Health and Society, UMAS Entrance 49, Malmö University, Södra Förstadsgatan 101, 20506 Malmö, Sweden. Tel.: +46 40665 7414; fax: +46 406658100 .

E-mail address: sergey.shleev@mah.se (S. Shleev).

URL: http://www.mah.se/shleev (S. Shleev).
}

of ascorbate oxidase (AOx), bilirubin oxidase (BOx), and laccase (Lc) containing four copper ions, $\mathrm{Cp}$ has six copper ions and is comprised of six compact $\beta$-barrel domains, with large loop insertions, giving the protein a unique triangular symmetry (Fig. 1).

However, the configuration of the copper ions is similar to that of other blue multicopper oxidases. In $\mathrm{Cp}$, three copper ions are situated in the T2/T3 cluster and three ions are bound to the three T1-binding sites [12]. The three copper ions of the trinuclear cluster lie at the interface between the first and last domains, 1 and 6 respectively, possessing ligands from each domain, an arrangement also seen in the structures of AOx [13] and Lc [14] (Fig. 1). The remaining three copper ions are mononuclear centres called $\mathrm{T} 1_{\text {Remote }}, \mathrm{T} 1_{\mathrm{CysHis}}$, and $\mathrm{T} 1_{\mathrm{PR}}$, held by intra-domain sites. $\mathrm{T} 1_{\text {Remote }}$ and $\mathrm{T} 1_{\text {CysHis }}$, located in domains 4 and 6 respectively, have a typical T1 copper environment with a set of four ligands: two histidines, one methionine and one cysteine (Fig. 1). The $\mathrm{T} 1_{\mathrm{PR}}$ site, located in domain 2 , has a different ligand structure in that it lacks the methionine, which is replaced in the amino acid sequence by a leucine residue, Leu329, analogous to the T1 site of some fungal Lcs [15]. The $\mathrm{T} 1_{\text {CysHis }}$ centre is connected to the T2/T3 cluster via the highly conserved Cys-2His electron transfer (ET) pathway, also found in the structures of AOx [13] and Lc [14], across a distance of approximately $13 \AA$ (Fig. $1 \mathrm{~A}$ ). It is widely held that $\mathrm{O}_{2}$ is bound and reduced to two $\mathrm{H}_{2} \mathrm{O}$ molecules at the three-nuclear copper cluster, whereas the mononuclear $\mathrm{T}_{1}$ Hiscys site is able to accept electrons from reduced substrates of $\mathrm{Cp}$, e.g. $\mathrm{Fe}$ (II) (Fig. 1A) [2,15]. In spite of the fast 


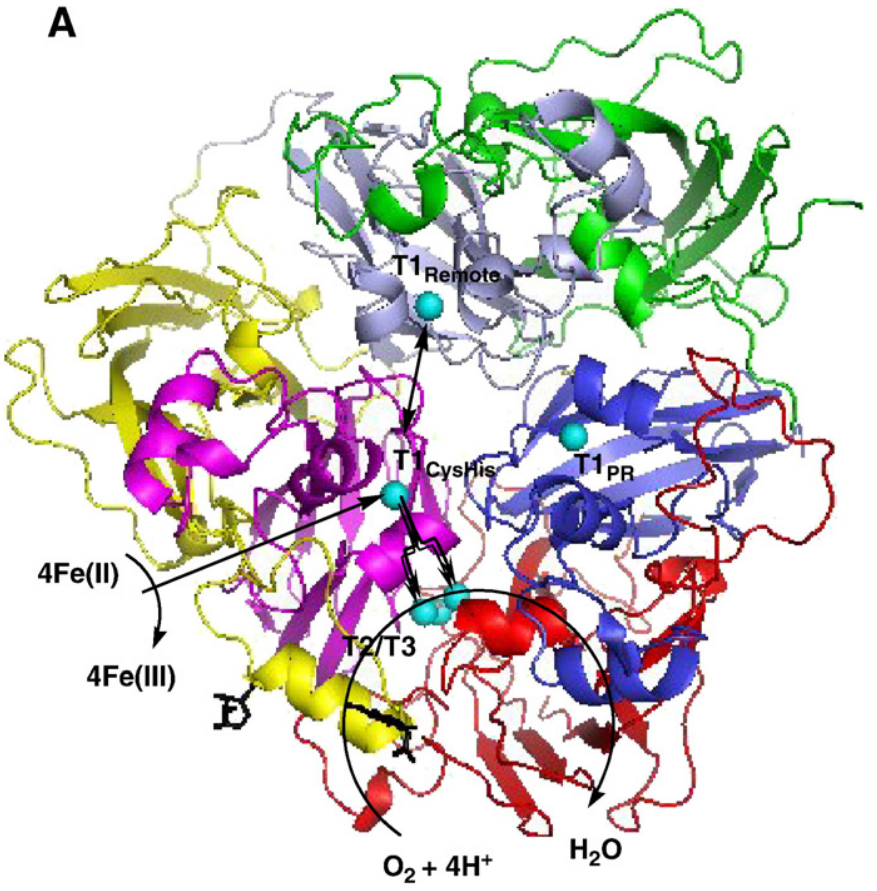

B

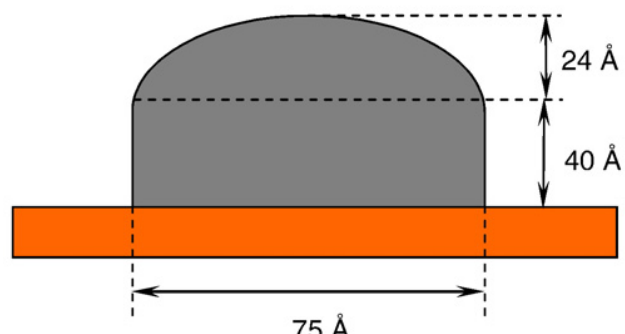

$75 \AA$

Fig. 1. (A) Proposed mechanisms of $\mathrm{Fe}(\mathrm{II})$ oxidation and $\mathrm{O}_{2}$ reduction by human $\mathrm{Cp}$. The three-dimensional structure of the enzyme was visualised using the program PyMOL $v$. 0.99 (PDB $1 \mathrm{KCW}$ ). The six domains are colour coded as red (1), blue (2), green (3), light blue (4), yellow (5), and purple (6). Six copper ions are shown in cyan and carbohydrates ( $n$-acetil-d-glucosamine) are in black. (B) Schematic view of a surfaceadsorbed $\mathrm{Cp}$ molecule consistent with a roughly native conformation (i.e. not significantly denatured).

electronic communication between $\mathrm{T} 1_{\text {HisCys }}$ and $\mathrm{T} 1_{\text {Remote }}\left(>150 \mathrm{~s}^{-1}\right)$ and the possibility for both centres to bind and oxidise $\mathrm{Fe}(\mathrm{II})$, the $\mathrm{T} 1_{\text {Remote }}$ site is not needed for oxidase activity of $\mathrm{Cp}$, but might be important in increasing the overall efficiency of Fe metabolism [15]. By contrast, the $\mathrm{T} 1_{\mathrm{PR}}$ copper site in human $\mathrm{Cp}$ is redox and catalytically irrelevant, characterised by extremely high redox potential (vide infra) and lacking the Cys-2His ET pathway to the T2/T3 cluster. This site could be a nonfunctional vestige of gene duplication [16].

The redox potentials of the $\mathrm{T} 1_{\text {CysHis }}$ and $\mathrm{T} 1_{\text {Remote }}$ copper sites $\left(E_{\mathrm{T} 1}\right)$ of human Cp were first measured by mediated redox titration in 1973 and were found to be $490 \mathrm{mV}$ and $580 \mathrm{mV} v$ s. NHE, respectively [17]. Later studies, however, suggested that the redox potentials of these sites are identical and equal to 448 and $434 \mathrm{mV}$ in phosphate buffer in the absence and presence of $\mathrm{Cl}^{-}$, respectively [15]. As for the $\mathrm{T} 1_{\mathrm{PR}}$ site, its $E_{\mathrm{T} 1}$-value was estimated to be very high, approximately $1000 \mathrm{mV}$ vs. NHE [16]. The redox potentials of the T2 and T3 sites were found to be 491 and $415 \mathrm{mV}$ respectively in phosphate buffer in the absence of $\mathrm{Cl}^{-}$, and 539 and $482 \mathrm{mV}$ respectively in the presence of $\mathrm{Cl}^{-}$[15].

The possibility of direct electron transfer (DET) between Cps of different origin and electrodes was the focus of investigations at different laboratories [18-20]. However, no electrochemical contact between the enzyme and any electrode [18] had been observed or only irreversible electrochemical activity from denaturated human and porcine $\mathrm{Cp}[19,20]$ was registered.

The only successful bioelectrochemical DET studies of the redox enzyme published in a peer-reviewed international journal were performed by Prof. Alexander I. Yaropolov with co-workers; Yaropolov was a visiting researcher at the group of Prof. Lo Gorton in the early 1990's [21]. Their collaborative work confirmed without a doubt the general possibility of DET between Cp and carbon or platinum electrodes using different electrochemical methods, such as voltammetry, potentiometry, and spectroelectrochemistry. Subsequently, one of the main thrusts of the scientific activity of Prof. Gorton was related to DET investigations of multicopper oxidases from different sources [22,23]. Well-pronounced bioelectrocatalytic reduction of $\mathrm{O}_{2}$ by plant and fungal laccases [21,24], as well as BODs [25,26] adsorbed on graphite electrodes, was shown. However, complete inability of adsorbed $\mathrm{Cp}$ to accelerate electroreduction of $\mathrm{O}_{2}$ was also observed $[21,23]$. In work to be reported below, we revisit the case of $\mathrm{Cp}$, reporting not only new data, but also a new functional interpretation of known facts about $\mathrm{Cp}$ based on ideas developed by the Gorton group over the last few years.

Developments in nanotechnology, by greatly expanding the range of surfaces that can be considered as potential electrodes, created additional possibilities for fundamental electrochemical studies of redox enzymes and their application in bioelectronics [27-29]. Here we report DET studies of human Cp immobilised on bare graphite and gold $(\mathrm{Au})$ electrodes, as well as on electrodes modified with carbon nanotubes (CNT) or Au nanoparticles (Au NP). We also considered thiol-modified Au surfaces. In spite of the variety of immobilisation methods used in the present studies, the previously observed inability of adsorbed $\mathrm{Cp}$ to catalyse electroreduction of $\mathrm{O}_{2}$ was confirmed. Possible reasons for such anomalous behaviour of this enzyme are suggested using a modern comprehensive picture of the thermodynamics and kinetics of the mechanism of $\mathrm{Cp}$ function.

\section{Materials and methods}

\subsection{Chemicals}

$\mathrm{Na}_{2} \mathrm{HPO}_{4}, \mathrm{KH}_{2} \mathrm{PO}_{4}, \mathrm{KCl}, \mathrm{NaCl}, \mathrm{NaF}, \mathrm{H}_{2} \mathrm{O}_{2}, \mathrm{H}_{2} \mathrm{SO}_{4}, \mathrm{HNO}_{3}$, and $\mathrm{NaF}$ were obtained from Merck (Darmstadt, Germany). Single- and multiwall carbon nanotubes (SWCNT and MWCNT, respectively), N-(3dimethylaminopropyl)-N'-ethylcarbodiimide hydrochloride (EDC), n-hydroxysuccinimide (NHS), 4-aminothiophenol (AMTP), and 6mercapto-1-hexanol (MHOL) were from Sigma-Aldrich (St. Louis, MO, USA). 3-mercaptopropionic acid (MPA) and $\mathrm{NaIO}_{4}$ were from Janssen Chimica (Geel, Belgium). Absolute ethanol (99.7\%) was from Solveco Chemicals AB (Täby, Sweden). 1-decanethiol (DT) was obtained from Fluka (Buchs, Switzerland). Trisodium citrate-2hydrate was from Riedel-de Haën (Seelze, Germany). All chemicals were analytical grade. Buffers were prepared with water (18 $\mathrm{M} \Omega$ ) purified with a PURELAB UHQ II system from ELGA Labwater (High Wycombe, UK). Anaerobic conditions were established using nitrogen $\left(\mathrm{N}_{2}\right)$ from AGA Gas AB (Sundbyberg, Sweden) that was bubbled through the working solutions.

\subsection{Biopreparations}

Human ceruloplasmin (Cp) was purchased from Sigma-Aldrich and used without further purification. The concentration of the enzyme in the stock solution was determined by the established method of Ehresmann [30]. Human serum, originated from one apparently healthy male volunteer, was prepared by a standard method known in the art and stored at $+4{ }^{\circ} \mathrm{C}$ until use. For serum preparation, 9NC tubes from BD Vacutainer $^{\circledR}$ (Plymouth, UK) were used. 


\subsection{Synthesis and characterisation of gold nanoparticles}

Au NP were synthesised as described in [31]. Briefly, $50 \mathrm{ml}$ of $1 \mathrm{mM}$ $\mathrm{HAuCl}_{4} \times \mathrm{H}_{2} \mathrm{O}$ solution was heated to boiling temperature with stirring; then $2.96 \mathrm{ml}$ of $1 \%$ trisodium citrate was added to the solution. The heating was continued for 15 min with stirring, and for a further $10 \mathrm{~min}$ without stirring. After cooling down to room temperature, the solution was dialysed against $\mathrm{H}_{2} \mathrm{O}$ at the volume ratio $1: 200$ for $12 \mathrm{~h}$ in order to remove excessive citrate.

To estimate the size of the Au NP, the theoretical light absorption spectrum was generated using the Mie-scattering algorithm in the MiePlot software (http://www.philiplaven.com/mieplot.htm). Depending on the size of NP, the shape of spectrum and absorption peak maximum is different, and the properties of theoretical spectrum should be close to the spectrum of the Au NP solution if the size of NP set up in the algorithm is the same as in the real solution. In the software the parameters were chosen as follows: refractive index of medium (water) - 1.3313847, Au sphere real - 0.1557086, Au sphere imaginary -3.6016265 at $23{ }^{\circ} \mathrm{C}$. The algorithm was set to Mie and Qext/Qsca/Qabs $v$ wavelength, and the radius of the particles was set to $25 \mathrm{~nm}$. The generated light absorption spectrum (Qext part) was compared to the spectrum of the synthesised Au NP, with the peak maximum at $530 \mathrm{~nm}$, and of $25 \mathrm{~nm}$ achieved radius (Fig. 2A).

\subsection{Electrochemical measurements}

\subsubsection{Cyclic voltammetry}

Cyclic voltammetry (CV) was performed in an electrochemical cell of volume $20 \mathrm{ml}$ containing an $\mathrm{Ag}|\mathrm{AgCl}| 3 \mathrm{M} \mathrm{KCl}(210 \mathrm{mV}$ vs. NHE) reference electrode and a platinum mesh counter electrode using a

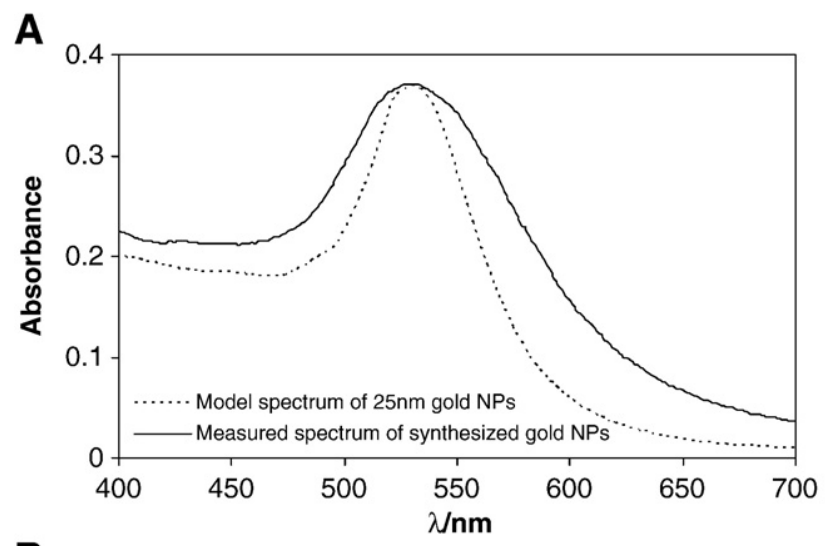

B

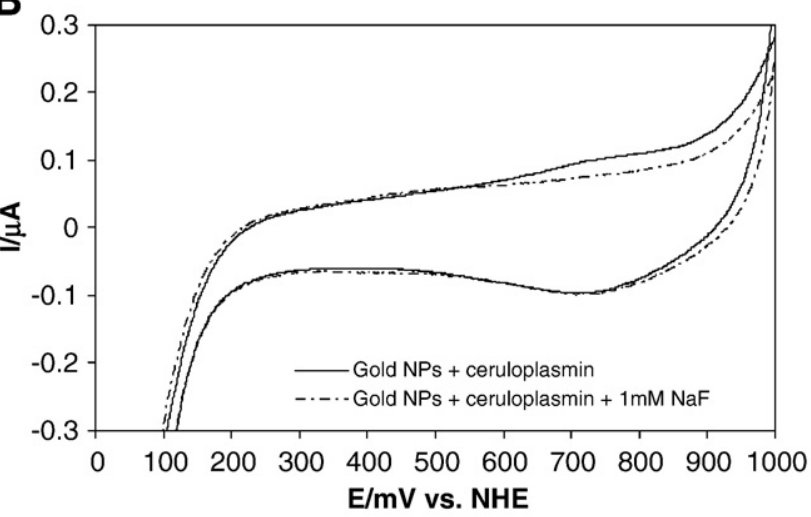

Fig. 2. (A) The recorded and modelled spectra of $25 \mathrm{~nm}$ radius gold nanoparticle solution. (B) CVs of a bare Au-nanoparticle-modified gold electrode and an electrode modified with $\mathrm{Cp}$ in the absence and presence of $10 \mathrm{mM} \mathrm{NaF}(0.1 \mathrm{M}$ air-saturated phosphate buffer, $\mathrm{pH} 7.4$; scan rate $10 \mathrm{mV} \mathrm{s}^{-1}$; starting potential $-1000 \mathrm{mV}$ ). potentiostat/galvanostat 2059 combined with a function generator 7800 from Amel Instruments (Milano, Italy). As supporting electrolytes the following solutions were used: (i) $0.1 \mathrm{M}$ phosphate buffer solution, $\mathrm{pH}$ 7.4; (ii) $0.1 \mathrm{M}$ phosphate buffer solution, $\mathrm{pH} 7.4$ with $\mathrm{Cl}^{-}$ $(150 \mathrm{mM})$ or $\mathrm{F}^{-}(10 \mathrm{mM})$; and (iii) human serum. All potentials in the present work are given $v$ s. NHE.

Three types of working electrodes were used in our studies: (i) disk $\mathrm{Au}$ electrodes purchased from Bioanalytical Systems (West Lafayette, IN, USA) with geometrical area of $0.02 \mathrm{~cm}^{2}$; (ii) Au substrates manufactured in a Balzers UMS 500 P system by electronbeam deposition of $2000 \AA$ of Au onto silicon (100) wafers (planar Au electrodes) that had been precoated with a 25 - $\AA$-thick titanium adhesion layer (Laboratory of Applied Physics, Linköping University, Sweden) with geometrical area of about $0.32 \mathrm{~cm}^{2}$; and (iii) spectrographic graphite electrodes (SPGE) from Ringsdorff Werke GmbH (Bonn, Germany, type RW001, 13\% porosity) with geometrical area of $0.073 \mathrm{~cm}^{2}$.

SPGE were polished with wet fine emery paper (Tufback Durite, P1200), rinsed thoroughly with $\mathrm{H}_{2} \mathrm{O}$ and allowed to dry. The adsorptive roughness factor of such an electrode was estimated previously to be about 5 [32].

Both types of Au electrodes, disk and planar, were cleaned by a series of CV scans at a $100 \mathrm{mV} \mathrm{s}^{-1}$ scan rate between 0 and $+1900 \mathrm{mV}$ vs. NHE in $0.5 \mathrm{M} \mathrm{H}_{2} \mathrm{SO}_{4}$. Immediately before usage they were rinsed thoroughly with $\mathrm{H}_{2} \mathrm{O}$. In addition, the disk Au electrodes were precleaned by CV scans at a rate of $100 \mathrm{mV} \mathrm{s}^{-1}$, between 0 and $-1400 \mathrm{mV}$ $v s$. NHE in $0.5 \mathrm{M} \mathrm{NaOH}$, then polished with a DP-suspension $(1 \mu \mathrm{m}$ high performance diamond product) and an alumina de-agglomerated polishing suspension ( $0.1 \mu \mathrm{m}$, Struers, Copenhagen, Denmark), rinsed with Millipore $\mathrm{H}_{2} \mathrm{O}$, and sonicated in $\mathrm{H}_{2} \mathrm{O}$ for 10 min after each polishing step. The microscopic roughness factors of Au electrodes were calculated from the charge $\left(q_{\text {real }}\right)$ associated with the Au oxide reduction process, obtained when running a CV from 0 to $1900 \mathrm{mV} v s$. NHE in $0.5 \mathrm{M} \mathrm{H}_{2} \mathrm{SO}_{4}$. The theoretical charge density $\left(\sigma_{t}\right)$ associated with the reduction of the Au oxide is $390 \pm 10 \mu \mathrm{C} \mathrm{cm}^{-2}$ [33].

When Au disk electrodes were modified by Au NP, the electrodes were etched for $10 \mathrm{~s}$ in aqua regia-like solution produced by freshly mixing concentrated $\mathrm{HNO}_{3}$ and $\mathrm{KCl}$ in a volumetric ratio of $1: 3$, thoroughly rinsed with $\mathrm{H}_{2} \mathrm{O}$, and polished with a DP-suspension to obtain as smooth a surface as possible, then rinsed with $\mathrm{H}_{2} \mathrm{O}$, and sonicated for $10 \mathrm{~min}$.

2.4.1.1. Immobilisation of $C p$ on bare and thiol-modified planar gold electrodes. For physical absorption of $\mathrm{Cp}$ on the disk Au electrode, a drop of $10 \mu \mathrm{l}$ of $\mathrm{Cp}\left(10 \mathrm{mg} \mathrm{ml}^{-1}\right.$ in $10 \mathrm{mM}$ phosphate buffer, $\mathrm{pH}$ 6.0) was placed on the Au surface. The electrode was covered to avoid evaporation and left to adsorb the protein for $3 \mathrm{~h}$. For covalent binding of $\mathrm{Cp}$, the Au electrode was first prepared by immersion in $10 \mathrm{mM}$ 4-aminothiophenol (ethanol solution) for $4 \mathrm{~h}$. The covalent binding was carried out using two different procedures (Scheme 1 ). In the first procedure, $2 \mu \mathrm{l}$ of $\mathrm{Cp}\left(10 \mathrm{mg} \mathrm{ml}^{-1}\right.$ in $10 \mathrm{mM}$ phosphate buffer, $\mathrm{pH}$ 6.0) was deposited onto the monolayer-modified Au electrode. After $15 \mathrm{~min}, 4 \mu \mathrm{l}$ of $10 \mathrm{mM}$ phosphate buffer, pH 6.0, containing $35 \mathrm{mM}$ NHS and $52 \mathrm{mM}$ EDC, was added for covalent binding between the carboxylic groups of the protein and the amine groups of the monolayer, and left to react for $2 \mathrm{~h}$ (Scheme $1 \mathrm{~A}$ ). In the second procedure, $10 \mu \mathrm{l}$ of $\mathrm{Cp}\left(10 \mathrm{mg} \mathrm{ml}^{-1}\right.$ in $10 \mathrm{mM}$ phosphate buffer, pH 6.0) was transferred into $200 \mu \mathrm{l}$ of a $10 \mathrm{mg} \mathrm{ml}^{-1}$ solution of $\mathrm{KIO}_{4}$ in water and left to react for $30 \mathrm{~min}$. After that, $400 \mu \mathrm{l}$ of $100 \mathrm{mM} \mathrm{Na}_{2} \mathrm{HPO}_{4}$ was added to raise the $\mathrm{pH}$ to 7 . The monolayermodified electrode was immersed in this solution for $1 \mathrm{~h}$, to enable the reaction of the oxidised sugar residues of the protein to form a Schiff base with the primary amine present in the monolayer (Scheme 1B). Before measurement the electrodes were carefully washed with buffer. 
A

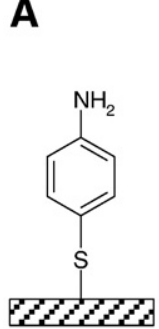

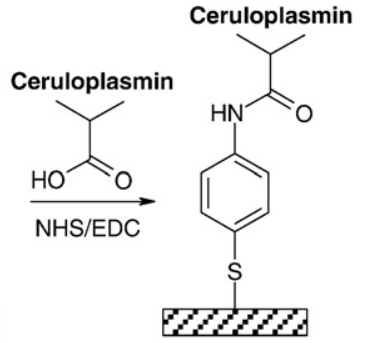
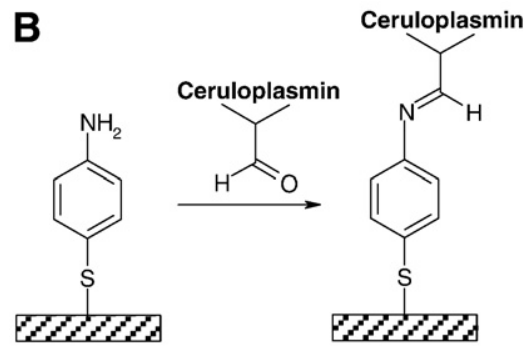

Scheme 1. Covalent immobilisation of $\mathrm{Cp}$ on the amino-modified gold surfaces.

2.4.1.2. Immobilisation of $C p$ on gold-nanoparticle-modified gold electrodes. First, Au electrodes were modified with Au NP: $10 \mu \mathrm{l}$ of a solution containing NP was added on the tip of the electrode, after which the electrode was allowed to dry and then rinsed thoroughly with $\mathrm{H}_{2} \mathrm{O}$. Second, $10 \mu \mathrm{l}$ of $\mathrm{Cp}\left(10 \mathrm{mg} \mathrm{ml}^{-1}\right.$ in $10 \mathrm{mM}$ phosphate buffer, $\mathrm{pH}$ 6.0) was placed on the Au surface. The electrode was covered to avoid evaporation and left to react for $90 \mathrm{~min}$.

2.4.1.3. Immobilisation of $C p$ on bare and CNT-modified SPGEs. A volume of $10 \mu \mathrm{l}$ of $\mathrm{Cp}$ solution ( $c a .1 \mathrm{mg} \mathrm{ml}^{-1}$ in $5 \mathrm{mM}$ phosphate buffer, $\mathrm{pH}$ 7.4) was placed on the cleaned bare or CNT-modified SPGE surface and allowed to adsorb for $30 \mathrm{~min}$.

The nanotube-modified SPGEs were obtained as described in [34]. Briefly, a solution of SWCNT or MWCNT $\left(10 \mathrm{mg} \mathrm{ml}^{-1}\right.$ in $5 \mathrm{mM}$ phosphate buffer, $\mathrm{pH}$ 7.4) was sonicated for $10 \mathrm{~min}$, diluted with ethanol to a final concentration of $0.5 \mathrm{mg} \mathrm{ml}^{-1}$; then $10 \mu \mathrm{l}$ of the solution was placed onto the SPGE surface and left to evaporate.

SPGE electrodes were also modified with a mixture of CNT and Cp. In this case, $10 \mu \mathrm{l}$ of SWCNT or MWCNT $\left(1 \mathrm{mg} \mathrm{ml}^{-1}\right.$ in $5 \mathrm{mM}$ phosphate buffer, pH 7.4) were mixed with $10 \mu \mathrm{l}$ of $\mathrm{Cp}\left(1 \mathrm{mg} \mathrm{ml}^{-1}\right.$ in $5 \mathrm{mM}$ phosphate buffer, $\mathrm{pH}$ 7.4), shaking the solution from time to time. After $1 \mathrm{~h}, 10 \mu \mathrm{l}$ of the mixture was placed onto the SPGE surface and left to evaporate.

\subsubsection{Chronoamperometry}

Chronoamperometric measurements were performed using a BAS CV-50 W voltammetric analyser (BAS, Bioanalytical Systems, West Lafayette, IN, USA) with a silver wire as a combined reference and counter electrode and the Au plate or SPGE as working electrode. The chronoamperometric current responses were registered during 10 min under aerobic and anaerobic conditions at room temperature. Three potentials were applied, viz. 350, 550, and $750 \mathrm{mV}$ vs. NHE using two different supporting electrolytes: $10 \mathrm{mM}$ phosphate saline buffer (PBS), pH 7.4 with $137 \mathrm{mM} \mathrm{NaCl}$ and $2.7 \mathrm{mM} \mathrm{KCl}$, or human serum. Current responses were recorded for bare and thiol-modified Au electrodes and bare SPGE with and without immobilised Cp.

\subsection{Ellipsometry measurements}

The adsorption of $\mathrm{Cp}$ onto bare or thiol-modified Au was studied with the in situ ellipsometry technique, which measures the changes in polarisation state of light which is reflected at a planar surface. A thin film automated ellipsometer (type 43 603-200E, Rudolph Research, Fairfield, NJ, USA) was equipped with a xenon lamp with a fixed angle of incidence $\left(67.8^{\circ}\right)$. The light was detected at $442.9 \mathrm{~nm}$ employing an interference filter with ultraviolet and infrared blocking (Melles Griot, Netherlands). The Au surface was vertically mounted into a glass trapezoid cuvette (Hellma, Germany) containing $6 \mathrm{ml}$ of solution, which was thermostated at $25{ }^{\circ} \mathrm{C}$ and stirred using a magnetic stirrer with a rotation speed of $325 \mathrm{rpm}$. The changes in ellipsometric angles were recorded in situ every $15 \mathrm{~s}$. In order to determine the refractive index of the surface, a two-zone surface calibration in buffer solution was carried out prior to each measurement. When $\mathrm{Cp}$ was to be adsorbed on the cleaned Au plate, first a stable baseline acquisition was done, and then enzyme from the stock solution was added to the cuvette containing $10 \mathrm{mM}$ PBS buffer at $\mathrm{pH}$ 7.4 , to a final concentration of $0.5 \mathrm{mg} \mathrm{ml}^{-1}$. The formation of protein film was monitored for $30 \mathrm{~min}$, followed by rinsing in PBS buffer for $5 \mathrm{~min}$. Cp was also immobilised on a 4-aminothiophenol-modified surface, prepared by immersion of the Au plate in $10 \mathrm{mM}$ ethanolic thiol solution for $4 \mathrm{~h}$. The sugar residues of protein were oxidised according to the procedure described in Section 2.4.1.1, by addition of $100 \mu \mathrm{l}$ of $\mathrm{Cp}\left(10 \mathrm{mg} \mathrm{ml}^{-1}\right)$ to $2 \mathrm{ml}$ of $10 \mathrm{mg} \mathrm{ml}^{-1} \mathrm{KIO}_{4}$ water solution and a 30 min reaction. Subsequently, the whole reaction solution was added to the cuvette filled with $4 \mathrm{ml}$ of $100 \mathrm{mM} \mathrm{Na}_{2} \mathrm{HPO}_{4}$ buffer with the thiol-modified Au surface already installed. The reaction was monitored for $1 \mathrm{~h}$ followed by rinsing of the cuvette for $5 \mathrm{~min}$ with phosphate buffer at a continuous flow of $18 \mathrm{ml} \mathrm{min}^{-1}$, in order to monitor protein desorption.

From ellipsometric data, the absolute protein layer thickness as well as the adsorbed amount in pmol $\mathrm{cm}^{-2}$ were calculated using the value of $0.18 \mathrm{ml} \mathrm{g}^{-1}$ [35] as the refractive index increment with respect to change in protein concentration $(\mathrm{dn} / \mathrm{dc})$ and $\mathrm{MW}$ of $\mathrm{Cp}$ equal to $132 \mathrm{kDa}$ [12].

\section{Results}

\subsection{Electrochemistry of $\mathrm{Cp}$ on $\mathrm{Au}$}

Cyclic voltammograms (CVs) of Au NP-modified Au electrodes with physically adsorbed $\mathrm{Cp}$ in the presence and absence of $\mathrm{F}^{-}$are shown in Fig. 2B. An electrochemical process at ca. $730 \mathrm{mV}$ vs. NHE could be seen. This process could be assigned to the redox transformation of $\mathrm{Cp}$ though not with certainty. Moreover, CVs of macroscale planar bare Au disk electrodes with physically adsorbed $\mathrm{Cp}$ showed no redox transformation of the enzyme under either anaerobic or aerobic conditions in the potential range between 0 and $1000 \mathrm{mV} v \mathrm{~s}$. NHE at scan rates varying from 10 up to $1000 \mathrm{mV} \mathrm{s}^{-1}$ (Fig. 3A). Therefore, alternative modifications to the Au surfaces were tried in the hopes of achieving a proper enzyme orientation that would facilitate DET between copper ions of $\mathrm{Cp}$ and the Au electrodes.

The Au surfaces were modified with thiol monolayers providing hydrophobic, anionic-hydrophilic, cationic-hydrophilic, or chargeneutral hydrophilic surfaces. Generally, no redox transformation of the enzyme was observed when hydrophobic surfaces were made with decanethiol; when charge-neutral hydrophilic surfaces were made with 6-mercapto-1-hexanol; or when anionic-hydrophilic surfaces were made with 3-mercaptopropionic acid. Only the covalent binding of $\mathrm{Cp}$ to the cationic-hydrophilic Au surface realised by forming a Schiff base between the 4-aminothiophenol (ATP) and chemisorbed $\mathrm{Cp}$ was successful in obtaining a DET reaction. Fig. 3B shows the CVs of an ATP-Au electrode before and after the covalent linking of the enzyme and in the absence and presence of $\mathrm{O}_{2}$. Obviously, the shape of the control CVs at high redox potential of the monolayer-modified electrodes of Fig. 3B is quite different from those measured after $\mathrm{Cp}$ attachment. A single anodic redox peak was observed with a peak potential $\left(E_{\mathrm{p}}\right)$ of about $750 \mathrm{mV} v \mathrm{~s}$. NHE (Fig. 3B, arrow). Removal of $\mathrm{O}_{2}$ from the electrolyte solution had only a minor 
A

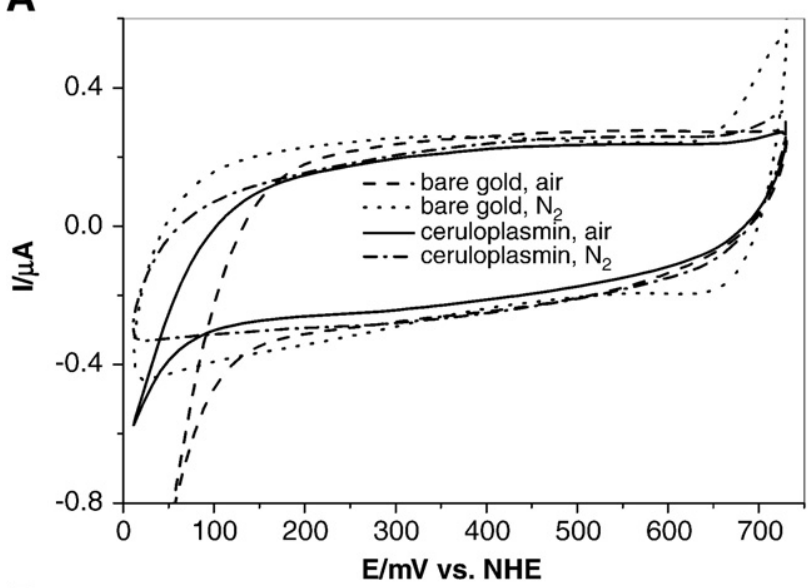

B

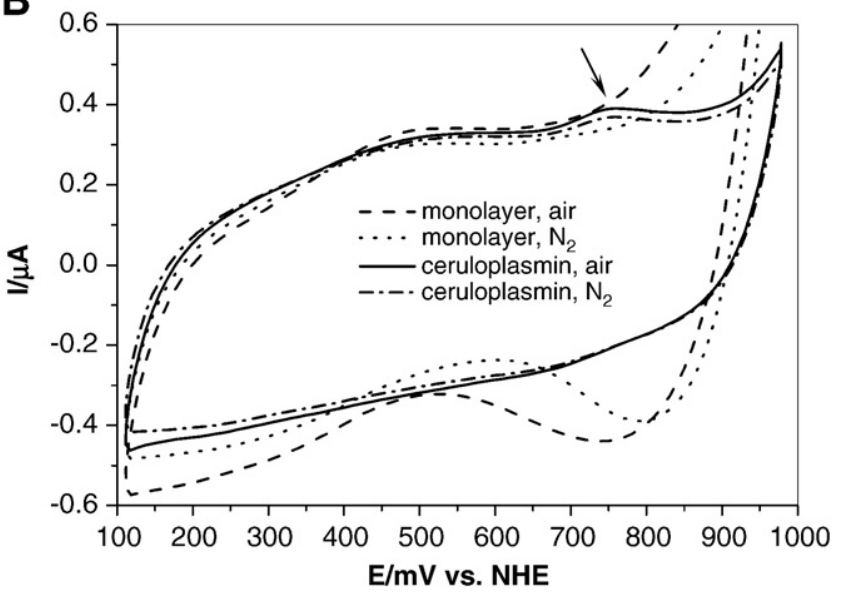

Fig. 3. CVs of planar gold electrodes with immobilised $\mathrm{Cp}$ (0.1 M phosphate buffer, $\mathrm{pH}$ 7.4; scan rate $-100 \mathrm{mV} \mathrm{s}^{-1}$ ). A and B represent CVs of a gold electrode with and without adsorbed $\mathrm{Cp}$ and a 4-amino-thiophenol-modified gold electrode with and without covalently attached $\mathrm{Cp}$, respectively.

effect on the CVs (Fig. 3B). Theoretically, the number of electrons transferred from the electrode to the $\mathrm{Cp}$ molecule can range from one to six but can realistically be assumed to be in the range 1 ([25]) to 4 ([36]) or 5 ( $\mathrm{T} 1_{\mathrm{PR}}$ is electronically isolated from the other five $\mathrm{Cu}$ ion sites). The corresponding concentrations of electroactive $\mathrm{Cp}$ on the ATP-Au surface would be in the range $1.6-7.8 \mathrm{pmol} \mathrm{cm}^{-2}$ taking into account the roughness factor of the electrode of about 2 . In spite of the observed DET reaction between NP- and thiol-modified Au electrodes and $\mathrm{Cp}$, no catalytic wave could be detected under air-saturated condition. In addition, chronoamperometric studies of bare and ATPmodified planar Au electrodes modified and unmodified with the redox protein under $\mathrm{N}_{2}$ and $\mathrm{O}_{2}$, in the presence and absence of enzyme inhibitor, $\mathrm{F}^{-}$, confirmed without a doubt the lack of bioelectrocatalytic activity of $\mathrm{Cp}$ adsorbed on Au surfaces (data not shown).

\subsection{Ellipsometry measurements}

To confirm the presence of the protein on bare and ATP-modified planar Au surfaces, ellipsometry studies were performed (Fig. 4). It was shown that adsorption of $\mathrm{Cp}$ on modified and unmodified $\mathrm{Au}$ surfaces is a rapid process which is finished within 10-15 min. An apparent lack of adsorption reversibility and very small desorption of the protein from the $\mathrm{Au}$ under rinsing conditions could also be observed. The total concentration of $\mathrm{Cp}$ (irrespective of its electronic connection to the electrode) on the bare Au surface was calculated to be about $3.3 \mathrm{pmol} \mathrm{cm}^{-2}$ and was present in a layer of absolute
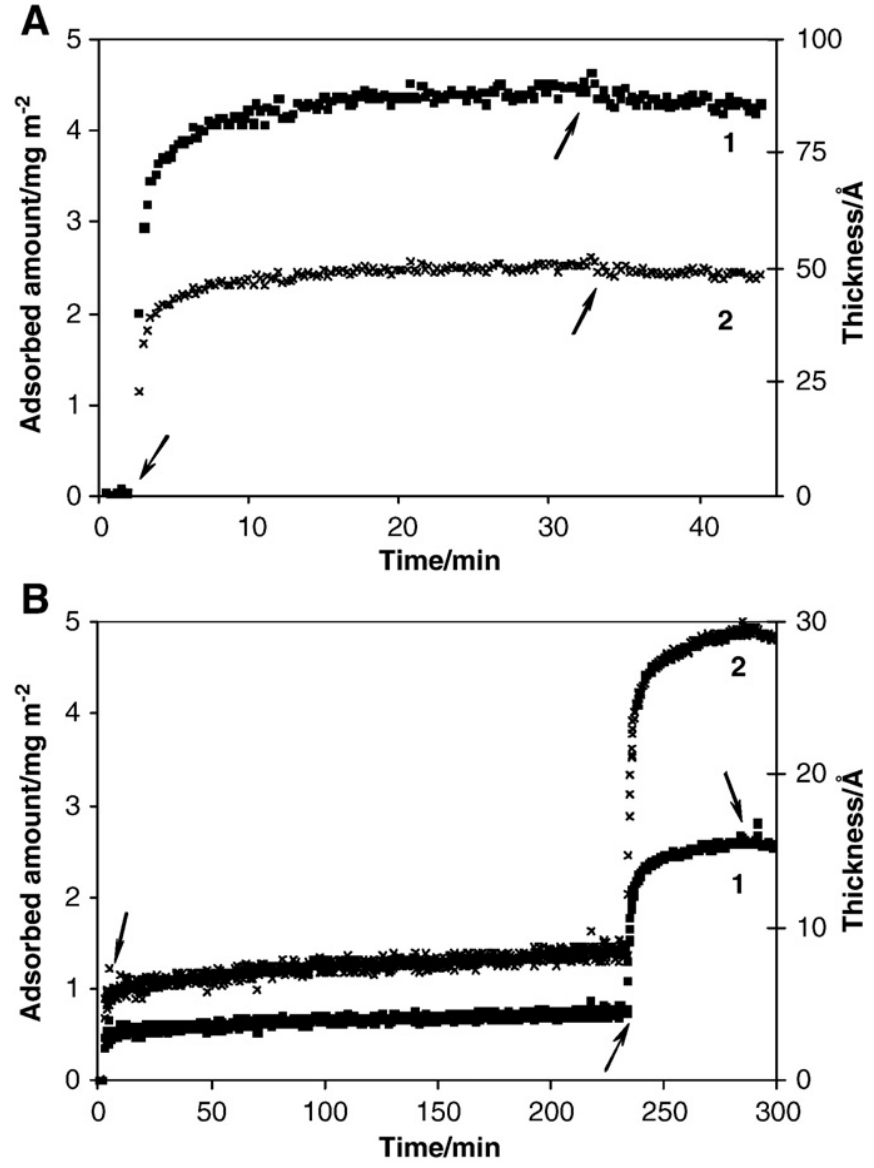

Fig. 4. Ellipsometry studies of $\mathrm{Cp}$ absorption on gold ( $0.05 \mathrm{M}$ phosphate buffer, $\mathrm{pH} 7.4$ containing $0.14 \mathrm{M}$ of $\mathrm{NaCl}$; adsorbed amount ( $\mathbf{\square}$, curve 1 ); thickness (x, curve 2). (A) Time dependence of adsorption of $\mathrm{Cp}$ on bare gold electrode surface. Arrows indicate first protein additions and then later rinsing with buffer. (B) Time dependence of adsorption of 4-amino-thiophenol on bare and $\mathrm{Cp}$ on the thiol-modified gold surface. Arrows indicate addition of thiol, addition of $\mathrm{Cp}$, and finally rinsing with buffer

thickness $50 \AA$ (Fig. 4A). This coverage is equal to the theoretical value for a compact monolayer of $\mathrm{Cp}$, which in the native conformation is roughly an equilateral triangle with side $75 \AA$ and height in the range 40-64 A, depending on the configuration of extending loops (Fig. 1B) [7].

The concentration of ATP on the bare Au surface was calculated to be about $700 \mathrm{pmol} \mathrm{cm}^{-2}$ and with an absolute thickness of about $8 \AA$

Table 1

Some parameters of bare and CNT-modified SPGEs with immobilised celuloplasmin (air-saturated 0.1 M phosphate buffer, pH 7.4).

\begin{tabular}{|c|c|c|c|c|c|c|}
\hline \multicolumn{2}{|l|}{ Parameters } & \multirow{2}{*}{$\begin{array}{l}\text { Bare } \\
340\end{array}$} & \multirow{2}{*}{$\begin{array}{l}\text { SWCNT } \\
335\end{array}$} & \multirow{2}{*}{$\frac{\text { MWCNT }}{330}$} & \multirow{2}{*}{$\frac{\text { SWCNT }^{*}}{365}$} & \multirow{2}{*}{$\begin{array}{l}\text { MWCNT* } \\
345\end{array}$} \\
\hline Cathodic wave & Potential (mV) & & & & & \\
\hline & $\begin{array}{l}\text { Coverage } \\
\left(\mathrm{pmol} \mathrm{cm}^{-2}\right)\end{array}$ & 42 & 214 & 155 & 124 & 149 \\
\hline & Potential (mV) & 580 & 580 & 585 & 625 & - \\
\hline & $\begin{array}{l}\text { Coverage } \\
\left(\mathrm{pmol} \mathrm{cm}^{-2}\right)\end{array}$ & 15 & 20 & 50 & 185 & - \\
\hline \multirow[t]{4}{*}{ Anodic wave } & Potential (mV) & 425 & 410 & 420 & 450 & 410 \\
\hline & $\begin{array}{l}\text { Coverage } \\
\left(\mathrm{pmol} \mathrm{cm}^{-2}\right)\end{array}$ & 72 & 425 & 188 & 209 & 155 \\
\hline & Potential (mV) & 790 & - & 790 & - & - \\
\hline & $\begin{array}{l}\text { Coverage } \\
(\text { pmol cm }\end{array}$ & n.d. & - & 18 & - & - \\
\hline
\end{tabular}

Notes: "*” - SPGE has been modified with a mixture of CNTs and Cp; “-“ - not observed "n.d." - not determined; the geometric area of $0.07 \mathrm{~cm}^{2}$ was used for calculation. 
A

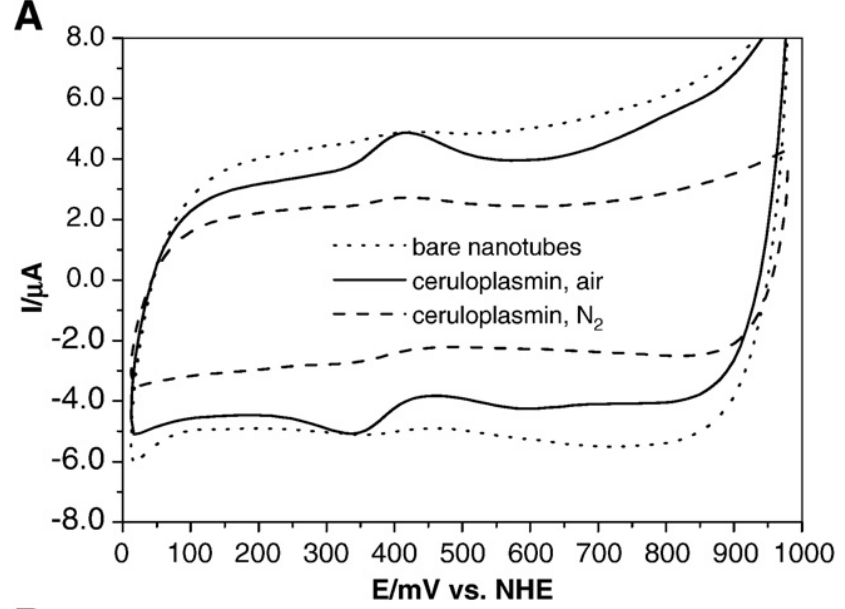

B

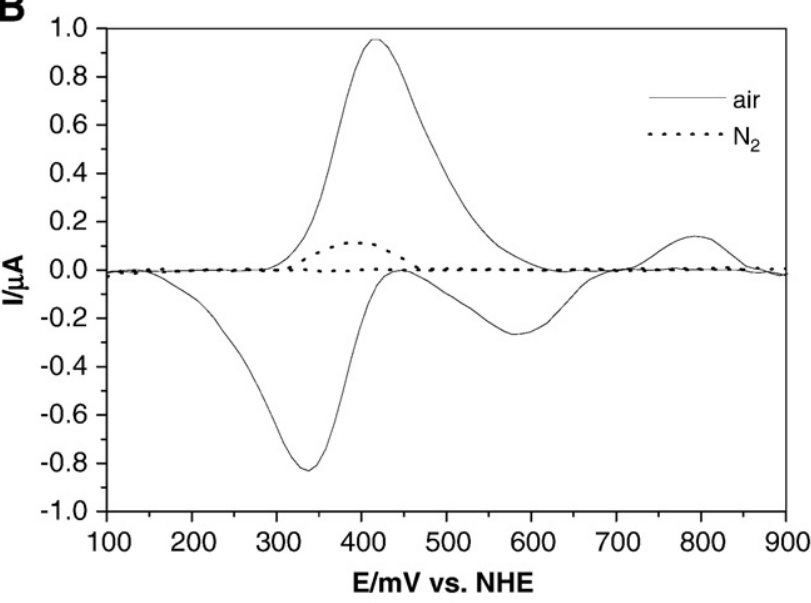

Fig. 5. CVs of MWCNT-modified SPGE with and without Cp (0.1 M phosphate buffer, $\mathrm{pH}$ 7.4; scan rate $-100 \mathrm{mV} \mathrm{s}^{-1}$; starting potential $-1000 \mathrm{mV}$ ). A and B represent raw CVs and background-current-subtracted CVs, respectively.

(Fig. 4A), which is quite close to the theoretical values for phenol monolayer on $\mathrm{Au}$ [37]. The concentration of $\mathrm{Cp}$ on the thiol-modified Au was found to be about $1.9 \mathrm{pmol} \mathrm{cm}{ }^{-2}$ with an absolute thickness of $21 \AA$ (Fig. 4B). These concentrations and thicknesses also conformed to expectations.

\subsection{Electrochemistry of $C p$ adsorbed on SPGEs}

In the presence of $\mathrm{O}_{2}$, one well-pronounced redox process was always observed in the raw CVs of human Cp directly adsorbed on bare and CNT-modified SPGEs with a midpoint potential $\left(E_{\mathrm{m}}\right)$ of about $390 \pm 18 \mathrm{mV}$ (Table 1 ).

For simplicity, only one case is presented in this report illustrating typical CVs of Cp-modified SPGE (Fig. 5A).

For most SPGE electrodes modified with the enzyme, an additional high redox potential cathodic wave appeared with an $E_{\mathrm{p}}$ of about $600 \pm 18 \mathrm{mV}$. On CVs of bare and MWCNT-modified SPGE with immobilised $\mathrm{Cp}$, an anodic wave also appeared resulting in $E_{\mathrm{m}}$ of about $690 \mathrm{mV} v$ s. NHE (Fig. 5). After subtracting the background, current voltammetric waves were symmetrical and well-defined. Peak separations $\left(\Delta E_{\mathrm{p}}\right)$ for the low and high redox potential Faradaic processes were $80 \pm 10 \mathrm{mV}$ and $205 \mathrm{mV}$, respectively (Fig. 5B). Calculations of the surface concentration of electroactive species $(\Gamma)$ from the charge associated with both anodic and cathodic waves were performed and values are presented in Table 1. As above, assuming an electron transfer process involving one to five electrons, the concentration of electroactive $\mathrm{Cp}$ on bare SPGE surface (unmodified with CNT) was in the range from 1.7 to 8.4 based on the low redox potential cathodic waves with $E_{\mathrm{p}}$ of $340 \mathrm{mV} v s$. NHE (Table 1), taking into account a roughness factor of the electrode equal to 5 . Using the high redox potential process the coverage was in the range from 0.6 to $3.0 \mathrm{pmol} \mathrm{cm}^{-2}$.

Since $\mathrm{Cl}^{-}$is an important, physiologically relevant effector of the redox potentials of the T2/T3 copper cluster in Cp [15], careful investigation of bioelectrochemical behaviour of the enzyme was performed in different media, including chloride-containing buffer and human serum, using CV and chronoamperometry. The low redox potential process with $E_{\mathrm{m}}$ of $390 \mathrm{mV}$ was slightly changed to the negative direction (ca. $15 \mathrm{mV}$ ) in the presence of $0.15 \mathrm{M}$ of $\mathrm{NaCl}$, whereas the high redox potential process was not affected by $\mathrm{Cl}^{-}$.

In spite of the well-pronounced DET, no catalytic wave of $\mathrm{O}_{2}$ electroreduction under air-saturated conditions was observed, neither when using phosphate buffers with and without $\mathrm{Cl}^{-}$, nor when using human serum, as supporting electrolytes. It is important to emphasise, however, that peak potentials and, especially, the intensity of registered Faradaic processes strongly depended on $\mathrm{O}_{2}$ concentration (e.g., Fig. 5). In the case of $\mathrm{Cp}$-modified SPGE, removal of $\mathrm{O}_{2}$ from the solution resulted in a significant increase of the intensity of the low potential process with an $E_{\mathrm{m}}$ shift of about $15 \mathrm{mV}$ in the negative direction along with the disappearance of the high potential nonturnover signal of the enzyme (not shown). For Cp-CNT-modified SPGE, removal of $\mathrm{O}_{2}$ from the solution resulted in almost complete disappearance of the electrochemical activity of the enzyme (Fig. 5).

\section{Discussion}

In the present studies, it appeared straightforward to immobilise significant amounts of $\mathrm{Cp}$ on Au and graphite surfaces, as verified using electrochemical and spectral techniques. It was shown previously that $\mathrm{Cp}$, when adsorbed on silicon wafers with a natural layer of silicon oxide, is oriented with one of its larger sides adjuncting the surface (Fig. 1B) [7]. This orientation seems also to be observed for the enzyme directly adsorbed on a bare Au surface. Because of the shape of the $\mathrm{Cp}$ molecule, the average thickness of the protein monolayer of $50 \AA$ A was registered, within the expected range of 64-40 A (Fig. 1B) [6]. The absolute thickness of the Cp layer on the ATP-modified Au surface was also substantial, though calculated to be less than on $\mathrm{Au}$, $21 \AA$ A. This is because only about half the amount of Cp was adsorbed on this surface compared to on the bare Au. Also, there is some uncertainty associated with the specific assumptions made about several parameters that enter into our calculations, such as refractive indices of ATP and Cp films formed in two ambient media (ethanol and buffer solution).

In spite of the very high concentrations of $\mathrm{Cp}$ on bare $\mathrm{Au}$ and graphite electrodes, ATP-modified Au and CNT-modified graphite electrodes, as well as the DET reaction observed between Cp and ATPmodified Au and all graphite electrodes, even minor acceleration of $\mathrm{O}_{2}$ electroreduction by $\mathrm{Cp}$ was never observed. This was the case using supporting electrolytes of different compositions and pHs, including the natural medium of this complex redox enzyme, human serum. In previous mediator-less studies of $\mathrm{Cp}$, a total inability of the adsorbed enzyme to reduce $\mathrm{O}_{2}$ was also observed $[21,38]$. It might be the case that the functionality of $\mathrm{Cp}$ is severely impaired in the surfaceadsorbed state. However, it was confirmed that $\mathrm{Cp}$ immobilised on carbon electrodes retains approximately $50 \%$ and $30 \%$ of its activity towards adrenaline and $\mathrm{Fe}(\mathrm{II})$, respectively, compared to the homogeneous oxidation of these substrates [38]. A significant decrease in turnover numbers of enzymes in heterogeneous reactions compared to homogeneous catalysis is a quite usual situation and does not necessarily imply partial denaturation of the protein on the electrode surface. Rather, it might reflect some diffusion limitations during heterogeneous catalysis. Also, as protein flexibility is essential for proper catalysis of blue multicopper oxidases [39], any restriction to $\mathrm{Cp}$ movements after adsorption on the surface will most likely 
influence the turnover number negatively. Indeed, it was postulated that the absence of bioelectrocatalytic activity of $\mathrm{Cp}$ is not related to the denaturation of the protein on the electrode surfaces, but rather reflects an ordered mechanism of Cp catalysis [40], during which an electrode cannot serve as a substrate of the enzyme [21,38]. Later, however, well-pronounced mediator-less bioelectrocatalysis for copper-containing complex redox enzymes, e.g. ascorbate oxidase [41] and copper nitrite reductase [42], was shown, even if ordered mechanisms were also suggested to explain the reduction of catalytic turnover in the heterogeneous state [43-45].

To find possible explanations for the inability of electrodeadsorbed $\mathrm{Cp}$ to accelerate electroreduction of $\mathrm{O}_{2}$, one should understand which copper site of this complex redox enzyme is in DET contact with the electrode. This is not an easy task. In general it is rather difficult to observe directly the electrochemical conversion of a copper centre of blue multicopper oxidases because of the large distance between the electrode and copper sites of the proteins, as well as the high affinity of these redox enzymes to $\mathrm{O}_{2}$. Anyhow, the electrochemical conversion of copper centre(s) of $\mathrm{Cp}$ immobilised on ATP-modified Au, bare graphite, and CNT-modified SPGEs, was clearly shown in the present work in agreement with previously published results on a simple surface $[21,38]$

Interestingly, the electrochemical behaviour of $\mathrm{Cp}$ adsorbed on bare SPGE is very similar to that of three-domain blue multicopper oxidases, BOx, adsorbed on the same electrodes ( $c f$. Fig. 5 in the present study with Fig. 1 in [25]). BOx contains only one T1 site, which is the first electron acceptor in homogeneous and heterogeneous catalyses, along with the T2/T3 copper cluster responsible for $\mathrm{O}_{2}$ reduction $[25,46]$. On CVs of BOx-modified SPGE, two nonturnover Faradaic signals with $E_{\mathrm{m}}$ of $690 \mathrm{mV}$ and $390 \mathrm{mV}$ were clearly observed under anaerobic conditions, and they are very similar in shape, intensity and $E_{\mathrm{p}}$ to those for Cp-SPGEs (Fig. 5; Table 1). Based on detailed spectroelectrochemical studies of different fungal BOxs [47], two processes with $E_{\mathrm{m}}$ of $690 \mathrm{mV}$ and $390 \mathrm{mV}$ were assigned to the redox transformations of the T1 site and the T2/T3 cluster of the enzyme, respectively [25]. In the case of human Cp, the $E_{\mathrm{m}}$ of the high potential Faradaic process is significantly higher than the reported redox potentials of the $\mathrm{T} 1_{\text {Cys-His }}$ and $\mathrm{T} 1_{\text {Remote }}$ sites of the enzyme (434-580 mV vs. NHE according to different authors [15,17]). However, this difference can be explained by a conformational transformation in the vicinity of the copper ions during adsorption of the enzyme. Moreover, a very minor change of this redox process on $\mathrm{Cl}^{-}$addition was registered in $\mathrm{CV}$ measurements, in agreement with the behaviour of the $\mathrm{T} 1$ sites observed during redox titration experiments [15]. Furthermore, as already shown for BOx, some values of redox potentials of the $\mathrm{T} 1$ sites of the blue multicopper oxidases are determined by the reductive titration procedure without electrochemical control, and reversible oxidative titrations were much smaller than the real potential of the T1 site of BOD carefully measured later on [47]. Thus, the general possibility that the nonturnover Faradaic process with $E_{\mathrm{m}}$ of $690 \mathrm{mV}$ belongs to either the $\mathrm{T} 1_{\text {Cys-His }}$ or $\mathrm{T} 1_{\text {Remote }}$ sites of $\mathrm{Cp}$ should not be prematurely rejected simply because of moderate disagreement between $E_{\mathrm{m}}$ in $\mathrm{CV}$ measurements and reductive redox titrations. In contrast, $\mathrm{T} 1_{\mathrm{PR}}$ of Cp was not, in all likelihood, electrochemically detectable under conditions used in the present work because of its very high redox potential.

As for the T2 and T3 copper sites, in our opinion, it is better to operate by the term of "redox potential of the T2/T3 copper cluster $\left(E_{\mathrm{T} 2 / \mathrm{T} 3}\right)$ ", since these two sites form the trinuclear cluster with maximal distance between all copper ions less than $5 \AA$ (Fig. 1A). The T2/T3 cluster of blue multicopper oxidases has many electronically and structurally different intermediates that form as the enzymatic reaction of $\mathrm{O}_{2}$ reduction progresses, and many $E_{\mathrm{T} 2 / \mathrm{T} 3}$-values of the cluster are expected [48]. The low potential Faradaic process with $E_{\mathrm{m}}$ of $390 \mathrm{mV}$ vs. NHE might be assigned as one of the redox potentials of the T2/T3 cluster of $\mathrm{Cp}$ because of its strong sensitivity towards $\mathrm{O}_{2}$ concentration. Moreover, one of the redox potentials of the cluster of blue multicopper oxidases, viz. fungal Lcs [23,48-50] and BOx [25,47], was also found to be $c a .400 \mathrm{mV}$, in agreement with the results obtained in the present study.

It should be mentioned, however, that some results of the present work contradict the hypothesis described just above that the two Faradaic processes observed for $\mathrm{Cp}$ should be described as the redox transformations of the T1 site and T2/T3 cluster. First, blue T1 sites of multicopper oxidases do not bind $\mathrm{O}_{2}$, and their nonturnover Faradaic signals should not be affected by $\mathrm{O}_{2}$ concentration. In our studies, however, the disappearance of the high redox potential process under anaerobic conditions is clearly seen (Fig. 5). Second, in accordance with redox titrations of $\mathrm{Cp}$, the redox potential of the T2/T3 copper cluster should be shifted to a higher value after addition of $\mathrm{Cl}^{-}$, an important and physiologically relevant effector of the redox potentials in human Cp [15]. In our studies, however, only a minor effect of $\mathrm{Cl}^{-}$ on redox processes was registered. Obviously, to unambiguously determine all redox potentials of different copper sites of $\mathrm{Cp}$, additional mediated and mediator-less spectroelectrochemical studies of the protein are needed. Such studies are in the scope of our further investigations.

To summarise, different immobilisation methods were exploited in our studies including nanotechnological achievements, i.e. use of $\mathrm{Au}$ NP and CNTs, in order to enhance surface texturing and thereby extend the range of the nature of the electrode surfaces that could be considered. In no case, however, was DET-based bioelectrocatalytic reduction of $\mathrm{O}_{2}$ by human $\mathrm{Cp}$ registered. At the same time, the electrochemical behaviour of Cp adsorbed on SPGE under anaerobic conditions mimics already published results concerning BOx-modified SPGE [25], for which well-pronounced bioelectrocatalysis was recently shown [25]. Thus, based on a modern comprehensive picture of the thermodynamics and kinetics of the mechanism of $\mathrm{Cp}$ function, one can suggest that the bioelectrocatalytic inertness of $\mathrm{Cp}$ is associated with a very complicated mechanism of intramolecular ET in this complex redox protein. It is widely held nowadays that all blue multicopper oxidases, including $\mathrm{Cp}$, couple the four-electron reduction of $\mathrm{O}_{2}$ to $\mathrm{H}_{2} \mathrm{O}$ with one-electron oxidation of substrates via a pingpong mechanism [15,51]. However, contrary to all other blue multicopper oxidases, the intramolecular ET from the $\mathrm{T} 1$ site $\left(\mathrm{T} 1_{\text {His-Cys }}\right.$, Fig. 1A) to the T2/T3 copper cluster does not occur, when only one reducing equivalent is donated to $\mathrm{T} 1$ coppers of $\mathrm{Cp}$. This reflects a kinetic trapping behaviour of this human enzyme [15], which might be the reason for the total absence of DET-based biocatalytic activity of Cp.

Cp shows commonalities with blue multicopper oxidases in general; yet $\mathrm{Cp}$ appears as an interesting case for which enzymatic function is not fully understood and may offer some unique surprises which await discovery and elucidation.

\section{Acknowledgments}

The authors thank Prof. Thomas Arnebrant and Prof. Tautgirdas Ruzgas (Biomedical Laboratory Science, Health and Society, Malmö University) for helpful suggestions and fruitful discussions. The work was supported financially by the Swedish Research Council (project 621-2005-3581), the Spanish Ministerio de Ciencia e Innovación (project CTQ2006-12097), and The European Commission (project MEST-CT-2004-514743). C. V.-D. thanks the FPU programm of Ministerio de Educatión y Ciencia for the fellowship.

\section{References}

[1] L. Calabrese, G. Musci, Molecular Properties of Ceruloplasmin from Different Species, Multi-Copper Oxidases, 1997, pp. 307-354.

[2] E.I. Solomon, U.M. Sundaram, T.E. Machonkin, Multicopper oxidases and oxygenases, Chem. Rev. 96 (1996) 2563-2605. 
[3] I. Bento, C. Peixoto, V.N. Zaitsev, P.F. Lindley, Ceruloplasmin revisited: structural and functional roles of various metal cation-binding sites, Acta Crystallogr. D63 (2007) $240-248$

[4] P.L. Fox, B. Mazumder, E. Ehrenwald, C.K. Mukhopadhyay, Ceruloplasmin and cardiovascular disease, Free Radic. Biol. Med. 28 (2000) 1735-1744.

[5] P.L. Fox, C. Mukhopadhyay, E. Ehrenwald, Structure, oxidant activity, and cardiovascular mechanisms of human ceruloplasmin, Life Sci. 56 (1995) 1749-1758.

[6] H.S. Hsieh, E. Frieden, Evidence for ceruloplasmin as a copper transport protein, Biochem. Biophys. Res. Commun. 67 (1975) 1326-1331.

[7] A. Rosengren, Cell-Protein-Material Interactions on Bioceramics and Model Surfaces, General Biochemistry, Uppsala Universitet, Uppsala, 2004, 72 pp.

[8] S. Shiva, X. Wang, L.A. Ringwood, X. Xu, S. Yuditskaya, V. Annavajjhala, H. Miyajima, N. Hogg, Z.L. Harris, M.T. Gladwin, Ceruloplasmin is a NO oxidase and nitrite synthase that determines endocrine NO homeostasis, Nat. Chem. Biol. 2 (2006) 486-493.

[9] H. Scheinberg, D. Gitlin, Deficiency of ceruloplasmin in patients with hepatolenticular degeneration. I, Science 116 (1952) 484-485

[10] S.C. Barton, J. Gallaway, P. Atanassov, Enzymatic biofuel cells for implantable and microscale devices, Chem. Rev. 104 (2004) 4867-4886.

[11] A. Heller, Miniature biofuel cells, Phys. Chem. Chem. Phys. 6 (2004) 209-216.

[12] V. Zaitsev, I. Zaitseva, G. Card, B. Bax, A. Ralph, P. Lindley, The three-dimensional structure of human ceruloplasmin at 3.0 Å resolution, Fold. Des. 1 (1996) S71

[13] A. Messerschmidt, R. Ladenstein, R. Huber, M. Bolognesi, L. Avigliano, R. Petruzzelli, A. Rossi, A. Finazzi-Agro, Refined crystal structure of ascorbate oxidase at $1.9 \AA$ resolution, J. Mol. Biol. 224 (1992) 179-205.

[14] K. Piontek, M. Antorini, T. Choinowski, Crystal structure of a laccase from the fungus Trametes versicolor at $1.90 \AA$ resolution containing a full complement of coppers, J. Biol. Chem. 277 (2002) 37663-37669.

[15] T.E. Machonkin, E.I. Solomon, The thermodynamics, kinetics, and molecular mechanism of intramolecular electron transfer in human ceruloplasmin, J. Am. Chem. Soc. 122 (2000) 12547-12560.

[16] T.E. Machonkin, H.H. Zhang, B. Hedman, K.O. Hodgson, E.I. Solomon, Spectroscopic and magnetic studies of human ceruloplasmin: identification of a redox-inactive reduced type 1 copper site, Biochemistry 37 (1998) 9570-9578.

[17] J. Deinum, T. Vänngård, The stoichiometry of the paramagnetic copper and the oxidation-reduction potentials of type I copper in human ceruloplasmin, Biochim. Biophys. Acta 310 (1973) 321-330.

[18] B.A. Kuznetsov, N.M. Mestechkina, G.P. Shumakovich, Electrochemical behavior of proteins containing coenzyme groups and metals, Bioelectrochem. Bioenerg. 4 (1977) 1-17.

[19] Razumas V., Vidugiris G., Zapalskyte A., Gudavicius A., Kulys J., Electrochemical conversion of lactoperoxidase, ceruloplasmin and alkaline phosphatase on mercury electrodes, Bioelectrochem. Bioenerg. 15 (1986) 407-415.

[20] M. Studnickova, J. Pitrincova, J. Kovar, The electrochemical behavior of copper proteins using differential pulse polarography, Bioelectrochem. Bioenerg. 25 (1991) 109-120.

[21] A.I. Yaropolov, A.N. Kharybin, J. Emnéus, G. Marko-Varga, L. Gorton, Electrochemical properties of some copper-containing oxidases, Bioelectrochem. Bioenerg. 40 (1996) 49-57.

[22] L. Gorton, A. Lindgren, T. Larsson, F.D. Munteanu, T. Ruzgas, I. Gazaryan, Direct Electron Transfer Between Heme-Containing Enzymes and Electrodes as Basis for Third Generation Biosensors, vol. 400, 1999, pp. 91-108.

[23] S. Shleev, J. Tkac, A. Christenson, T. Ruzgas, A.I. Yaropolov, J.W. Whittaker, L. Gorton, Direct electron transfer between copper-containing proteins and electrodes, Biosens. Bioelectron. 20 (2005) 2517-2554.

[24] S. Shleev, A. Jarosz-Wilkolazka, A. Khalunina, O. Morozova, A. Yaropolov, T. Ruzgas, L. Gorton, Direct electron transfer reactions of laccases from different origins on carbon electrodes, Bioelectrochemistry 67 (2005) 115-124.

[25] P. Ramirez, N. Mano, R. Andreu, T. Ruzgas, A. Heller, L. Gorton, S. Shleev, Direct electron transfer from graphite and functionalized gold electrodes to T1 and T2/T3 copper centers of bilirubin oxidase, Biochim. Biophys. Acta 1777 (2008) 1364-1369.

[26] S. Shleev, A. El Kasmi, T. Ruzgas, L. Gorton, Direct heterogeneous electron transfer reactions of bilirubin oxidase at a spectrographic graphite electrode, Electrochem. Commun. 6 (2004) 934-939.

[27] E. Katz, I. Willner, Biomolecule-functionalized carbon nanotubes: applications in nanobioelectronics, ChemPhysChem 5 (2004) 1084-1104.
[28] E. Katz, I. Willner, J. Wang, Electroanalytical and bioelectroanalytical systems based on metal and semiconductor nanoparticles, Electroanalysis 16 (2004) 19-44.

[29] N. Li, J. Wang, M. Li, Electrochemistry at carbon nanotube electrodes, Rev. Anal. Chem. 22 (2003) 19-33.

[30] B. Ehresmann, P. Imbault, J.H. Weil, Spectrophotometric determination of protein concentration in cell extracts containing tRNA and rRNA, Anal. Biochem. 54 (1973) 454-463.

[31] G. Schmid, B. Corain, Nanoparticulated gold: syntheses, structures, electronics, and reactivities, Eur. J. Inorg. Chem. (2003) 3081-3098.

[32] H. Jaegfeldt, T. Kuwana, G. Johansson, Electrochemical stability of catechols with a pyrene side chain strongly adsorbed on graphite electrodes for catalytic oxidation of dihydronicotinamide adenine dinucleotide, J. Am. Chem. Soc. 105 (1983) 1805-1814.

[33] S. Trasatti, O.A. Petrii, Real surface area measurements in electrochemistry, Pure Appl. Chem. 63 (1991) 711-734.

[34] M.C. Weigel, E. Tritscher, F. Lisdat, Direct electrochemical conversion of bilirubin oxidase at carbon nanotube-modified glassy carbon electrodes, Electrochem. Commun. 9 (2007) 689-693.

[35] J.A. De Feijter, J. Benjamins, F.A. Veer, Ellipsometry as a tool to study the adsorption behavior of synthetic and biopolymers at the air-water interface, Biopolymers 17 (1978) 1759-1772.

[36] M.H. Thuesen, O. Farver, B. Reinhammar, J. Ulstrup, Cyclic voltammetry and electrocatalysis of the blue copper oxidase Polyporus versicolor laccase, Acta Chem. Scand. 52 (1998) 555-562.

[37] J. Pinson, F. Podvorica, Attachment of organic layers to conductive or semiconductive surfaces by reduction of diazonium salts, Chem. Soc. Rev. 34 (2005) 429-439.

[38] A.L. Gindilis, A.I. Yaropolov, I.V. Berezin, Role of enzyme mechanism in the manifestation of its electrocatalytic properties, Dokl. Akad. Nauk SSSR 293 (1987) 383-386.

[39] I. Bento, L.O. Martins, G. Gato Lopes, M. Armenia Carrondo, P.F. Lindley, Dioxygen reduction by multi-copper oxidases; a structural perspective, Dalton Trans. (2005) 3507-3513.

[40] E.L. Saenko, O.B. Siverina, V.V. Basevich, A.I. Yaropolov, A kinetic study of the oxidase reaction of ceruloplasmin, Biokhimiya (Moscow) 51 (1986) 1017-1022.

[41] R. Santucci, T. Ferri, L. Morpurgo, I. Savini, L. Avigliano, Unmediated heterogeneous electron transfer reaction of ascorbate oxidase and laccase at a gold electrode, Biochem. J. 332 (1998) 611-615.

[42] J. Zhang, A.C. Welinder, A.G. Hansen, H.E.M. Christensen, J. Ulstrup, Catalytic monolayer voltammetry and in situ scanning tunneling microscopy of copper nitrite reductase on cysteamine-modified $\mathrm{Au}(111)$ electrodes, J. Phys. Chem. B 107 (2003) 12480-12484.

[43] L.C. Petersen, H. Degn, Steady-state kinetics of laccase from Rhus vernicifera, Biochim. Biophys. Acta 526 (1978) 85-92.

[44] R.W. Strange, L.M. Murphy, F.E. Dodd, Z.H. Abraham, R.R. Eady, B.E. Smith, S.S. Hasnain, Structural and kinetic evidence for an ordered mechanism of copper nitrite reductase, J. Mol. Biol. 287 (1999) 1001-1009.

[45] S.V. Antonyuk, R.W. Strange, G. Sawers, R.R. Eady, S.S. Hasnain, Atomic resolution structures of resting-state, substrate- and product-complexed Cu-nitrite reductase provide insight into catalytic mechanism, Proc. Natl. Acad. Sci. U.S.A. 102 (2005) 12041-12046.

[46] T. Sakurai, K. Kataoka, Structure and function of type 1 copper in multicopper oxidases, Cell. Mol. Life Sci. 64 (2007) 2642-2656.

[47] A. Christenson, S. Shleev, N. Mano, A. Heller, L. Gorton, Redox potentials of the blue copper sites of bilirubin oxidases, Biochim. Biophys. Acta 1757 (2006) 1634-1641.

[48] S. Shleev, T. Ruzgas, Transistor-like behavior of a fungal laccase, Angew. Chem., Int. Ed. 47 (2008) 7270-7274.

[49] M. Pita, S. Shleev, T. Ruzgas, V.M. Fernandez, A.I. Yaropolov, L. Gorton, Direct heterogeneous electron transfer reactions of fungal laccases at bare and thiolmodified gold electrodes, Electrochem. Commun. 8 (2006) 747-753.

[50] S. Shleev, M. Pita, A.I. Yaropolov, T. Ruzgas, L. Gorton, Direct heterogeneous electron transfer reactions of Trametes hirsuta laccase at bare and thiol-modified gold electrodes, Electroanalysis 18 (2006) 1901-1908.

[51] T.E. Machonkin, G. Musci, H.H. Zhang, M.C.B.D. Patti, L. Calabrese, B. Hedman, K.O Hodgson, E.I. Solomon, Investigation of the anomalous spectroscopic features of the copper sites in chicken ceruloplasmin: comparison to human ceruloplasmin, Biochemistry 38 (1999) 11093-11102. 